\title{
Intervening Effect of Financial Services on the Relationship Between Bank Restructuring and Financial Performance
}

\author{
Angela Mucece Kithinji, PhD Candidate \\ Dr. Mirie Mwangi, PhD, Senior Lecturer \\ Dr. Kate Litondo, PhD, Senior Lecturer \\ Professor Martin Ogutu, PhD, Prof. of Business Administration \\ University of Nairobi, School of Business, \\ Department of Business Administration, Nairobi, Kenya
}

Doi: 10.19044/esj.2017.v13n28p121 URL:http://dx.doi.org/10.19044/esj.2017.v13n28p121

\begin{abstract}
Previous studies on the relationship between bank restructuring and financial performance reveal conflicting results with few studies establishing the effect of financial services. Few studies have investigated the causality between bank restructuring and financial performance as intervened by deposits and customer loans. The positivism research philosophy and descriptive and inferential causal research design were used in this study. The hypothetical view of the study was that the relationship between bank restructuring and financial performance of commercial banks in Kenya is not intervened by deposits and customer loans. The 39 commercial banks that were consistently in business for the period 2002 to 2014 were included in the study. Bank restructuring was disaggregated into financial restructuring, capital restructuring, operational restructuring and asset restructuring. The empirical findings were as follows: There was a significant direct association between bank restructuring and financial performance which was intervened by deposits and customer loans as proxies for financial services. Deposits were found to be significant in intervening the relationship between bank restructuring and financial performance. Customer loans on the other had was not found to significantly intervene the relationship between bank restructuring and financial performance. A composite variable of financial services denoting the aggregate of the intervention of deposits and customer loans showed a significant intervening effect on the relationship between bank restructuring and financial performance. The study outcome therefore reveals that the hypothesis that the relationship between bank restructuring and financial performance is not intervened by financial services is rejected.
\end{abstract}


The conclusion is that banks should focus more on deposits to caution against a decrease in financial performance. Additionally customer loans should not be ignored since the intervention though insignificant tends to negatively influence financial performance. The implication is that when banks focus more on the provision of financial services they are likely to compromise financial finance possibly because of the increased costs associated with providing financial services. Regulatory institutions such as the Central Bank of Kenya (CBK) and the Kenya Institute of Bankers can use the study results to enhance policy and prudential guidelines to increase profitability of the banks. The study recommends that there is need to increase financial services offered by banks to increase outreach other than improving profitability of banks.

Keywords: Bank Restructuring, Financial performance, Financial Services, Bank Size, Bank Ownership

\section{Introduction}

Bank restructuring is majorly undertaken to enhance financial performance and sometimes, to impose checks and balances to reduce the possibility of a financial crisis which may either have local or global implications (Birchil \& Simmons, 2010). Generally, restructuring deals with the act of reorganizing the legal framework, ownership structure, operational activities, financial structure or other aspects of an organization for the purpose of enhancing its profitability and preparing it for its current needs (Hoenig \& Morris, 2012). Bank restructuring is intended to restore and maintain faith and confidence in the banking system and profitability and efficiency in the individual banks (Nor, et. al., 2009). Bank restructuring also refers to increasing surveillance and prudential regulation in order to increase the intermediation process of the banking system (Mario, 2014). Bank restructuring is sometimes undertaken to address the problems in individual banks experiencing banking crisis or to solve the problems affecting the entire banking system. Hoggarth et. al. (2004) and Emilia, Gupta and Weisin (2007) state that failure to recognize and take action with regard to individual banks can lead to a buildup of problem assets and institutions which increase the possibility of, and at the same time, hide more systemic problems calling for pre/non crisis bank restructuring. Diagonising banking problems before banking crisis ensue is necessary for ensuring a sound financial system (Hawkins \& Turner, 1999).

Following technological changes many banks have had to restructure to improve efficiency and to enhance coordination and facilitate consolidation of the activities arising from the expanded branch networks while having the motive of increasing profitability. The need for Automated 
Teller Machine (ATMs) networks, mobile banking, agency banking, bank assurance and faceless banking calls for banks to continuously embrace bank innovations to be able to increase their volume of business (Chang, et. al., 2014). Technological infrastructure has the effect of increasing a bank's assets and an increase in banks operations. Good infrastructure such as expanded branch network, installation of ATM network, opening of subsidiaries, use of internet banking, agency banking, and embracing ICT in processing financial transactions within the banking institution as well as across banking institutions are important infrastructural facilities that are necessary to fast track quick provision of financial services to banking sector clients. Bank restructuring is therefore essential to enable access of financial services by clients of banks.

Dziobek (1998) and Dziobek and Pazarbasioglu (1998) states that there are four main types of bank restructuring and they include; financial restructuring, operational restructuring, asset restructuring and capital restructuring. Financial restructuring focuses on the financial structure of the banking institution and is usually concerned about the liability and capital structures of banking institutions. The most significant part of the banks liabilities is customer deposits and long term debt tends to form a very small proportion of the financial structure of banking institutions. Rose (1994) state that operational restructuring focuses on reorganizing the activities of banks including their governance structure and also entails closing down or downsizing poorly performing entities or branches, downsizing and closing down product lines to reduce costs of bank operations. Dubel and Berlin (2013) observe that asset restructuring entails reducing the poor performance in banks by increasing the liquidity of assets by holding more of current assets while ensuring that a large proportion is financial assets, and reducing the level of non-performing loans through provisioning for problem loans and selling off bad loans. Capital restructuring involves increasing the financial performance in banks by way of substitution of short-term debt and junior long-term debt with longer- term debt obligations (by converting debt to equity) to increase the financial structure of banks (John, Daunders \& Senbet, 1995; Karacadag \& Taylor, 2000; Wall \& Peterson, 1995). It sometimes involves direct capital injection by the shareholders and other times a bailout by government whereby additional capital is channeled into the banking entity by government (Dziobek and Pazarbasioglu, 1998; Rose, 1994).

The link between bank restructuring and financial performance is anchored in the theory of financial intermediation by Merton (1995) that explains the existence of financial institutions and the fact that they are dependent on information asymmetry and are subjected to high transaction costs. When banks are inefficient in extending their financial services, they 
normally undergo restructuring by way of increasing the capital base, dealing with the problem of nonperforming loans or increasing their functions while maintaining or changing the status quo. Other strategies that commercial banks engage in to improve financial intermediation include mergers and acquisitions (Andries and Cuza, 2009). The financial intermediation theory contends that if savers and borrowers had a better way of convergence, and where financial market participants are able to access market information the role of financial institutions and financial regulation would significantly diminish. Where financial institutions including commercial banks exist information asymmetry, moral hazard and transaction costs are reduced (Klein, et. al., 2005).

The need to provide financial services to different types of clients explains the existence of financial intermediation role which focuses on the provision of financial services by financial institutions to the financial markets participants (Dupas \& Robinson, 2009). Financial services are the economic services provided by the financial industry, and include, a broad range of businesses that manage money, such as Credit Unions, commercial banks, credit-card companies, insurance companies, accountancy firms, consumer companies, stock brokerage firms, investment funds and certain government sponsored enterprises (Moore, 2003). The financial sector as the main intermediary between savers and borrowers on the one hand and investors on the other is an essential link in access to financial services (Das \& Ghosh, 2006). Commercial banks which are the main financial intermediaries are in the business of accepting deposits, extending loans to their customers, discovering new financial products, underwriting, and servicing of investments made using their own resources (Fried, Lovell \& Eeckaut, 1993). Suehiro (2002) states that successful restructuring of the banking system is dependent not only on the implementation of institutional reforms initiated by the government in accordance with the global standards but also to the development of self-efforts undertaken by leading local commercial banks for them to be able to effectively perform their financial intermediation role.

To enhance profitability, commercial banks need to earn high net interest income which means that interest rate on deposits has to be relatively low to avoid eroding high interest income (from loans) with high interest expense (paid to depositors) Honohan and King, 2009). In developing countries foreign banks provide a wide range of financial services and have greater margins and profits than domestic banks which are majorly governed through local ideologies. Foreign large banks are also more modernized and are more efficient than their local counter parts (Kwaning, Churchill \& Opuku, 2014). Large banks are known to be well capitalized and they tend to be more profitable because of their lower cost of funding and lower 
prospective bankruptcy costs. Banks with relatively high non-interest earning assets are less profitable since most banks rely on interest incomes, and banks that rely largely on deposits for their funding are less profitable as increasing deposits may require more branches that also increases overhead costs (Chang, et. al., 2014; Dubel \& Berlin, 2013).

According to Roberts (2007) the best performance measures contain inputs which facilitate organizations to focus their actions in achieving their long-term objectives. Measures of performance can be described as accounting measures, market based measures, the Tobin's Q, the Economic Value Added (EVA) and the non-accounting measures. Accounting measures are majorly financial measures of performance which rely on balance sheet and income statement data. Financial performance measures rely on financial information which may be qualitative or quantitative and are return on assets (ROA), return on equity (ROE) and return on sales (ROS) (Ho \& Mckay, 2002). Rose (1994) states that the main measures of performance of financial institutions are return on assets, return on equity, equity capital ratio, net interest margin, and the spread which is the difference between incomes from interest bearing assets and the expenses from interest paying liabilities.

Kaplan and Norton (1996) states that financial performance metric is essentially the ultimate measure of institutional performance. The author contends that the balanced scorecard approach is from the perspective that non-financial data and financial data which is necessary for measuring financial performance of firms is essentially obtained from credible sources. Kaplan \& Norton (2001) states that the performance measurement framework includes the aspects of financial perspective, internal business environment perspective, customer perspective and product innovations perspective. Every scorecard relies on the typical financial objectives of profitability, earnings of assets and mobilization of revenue. The financial perspective objective of the scorecard enables senior management of businesses to specify not only the metric by which the long-term success of the enterprise will be measured, but also the final result objectives. The measure of a manager's ability and effort is at the peak when the balanced score card is used and an interactive control system is put in place (Lipe \& Satterio, 2000).

Leah (2008) defined financial performance as the measurement of the outcome of a firm's strategies, policies and operations in monetary terms. The outcomes are reflected in the firm's return on assets and return on investments. Financial performance is also defined as the end result of primary utilization of firm assets to generate proceeds during ordinary business operations (Adams and Mehran, 2005). Waweru (2008) argues that financial performance can also be used as a general measure of a firm overall 
financial level over a particular time duration and can be used for comparison of general performance of different firms operating in the same industry. Financial performance is also stated as a gauge to express the general financial productivity of an organization over a span of financial period and aids in comparison of financial results of other firms in the same sector. There is no one universally accepted proxy for measuring the financial performance of a firm. The level of financial performance however explains the extent to which a firm has succeeded. From a wider perspective, financial performance of a firm take both the accounting and market based dimensions (Waweru, 2008; Waggoner, Neely \& Kennerley, 1999)

Accounting measures are majorly financial measures of performance which rely on balance sheet and income statement data. Financial performance measures rely on financial information which may be qualitative or quantitative and are return on assets (ROA), return on equity (ROE) and return on sales (ROS) (Ho \& Mckay, 2002). Rose (1994) states that the main measures of performance of financial institutions are return on assets, return on equity, equity capital ratio, net interest margin, and the spread which is the difference between incomes from interest bearing assets and the expenses from interest paying liabilities. The current study uses return on assets (ROA) as a measure of financial performance. Financial restructuring relied on changes in long-term debt to asset ratio, capital restructuring relied on changes in return on equity (ROE) and asset restructuring focused on the asset quality as measured using changes in nonperforming loans, which are accounting measures. Operational restructuring on the other hand relied on changes in Bank branches and Automated Teller Machines (ATMs) which is an operational variable and has cost implication, which again is another accounting measure.

\section{Literature Review}

The concept of bank restructuring has faced unresolved argument by researchers although it is a pivotal decision for banks as represented by the regularity of banks in injecting additional capital and the occasional government bailout whenever government owned banks experience a banking crisis. Rose (1994) examined the effect of financial, operational and asset restructuring on financial performance of banks that went through financial crisis in the form of negative profitability. The measures of financial performance were bank profitability and bank efficiency. Financial ratios used in the study were return on assets (ROA), return on equity (ROE), net interest margin (NIM) and the spread. The measure of operational restructuring was the income/cost ratio and the total operating costs to total assets. Financial restructuring was measured using long-term debt to total assets while asset quality was measured using non-performing loans to total 
loans and loan provisions to total loans. Regression results showed that the banks restructured reported positive and consistent increase in net profitability following bank restructuring.

Honohan and King (2009) finds that among the firm factors that determine access to financial services, efficiency and profitability are size, ownership and years in banking, access to financial services and size. A restructuring programme that calls for purchase of weak small banks by relatively large healthy banks introduction of mobile banking, having in place agency banking, expanding the ATM network, embracing branchless and faceless banking, use of Point of Sale (POS) terminals, extensive use of debit cards and credit cards is essential for larger profitable and more efficient banks.

De Young and Rice (2003) establish a number of research links between noninterest income of banks, business strategies, market conditions, technological change, and financial performance of banks for the period 1989 and 2001. Diversification into non-interest activities enabled the financial institution to increase its profitability. The results indicate that banks that are managed properly expand more slowly into noninterest activities to diversify their profits, and that increases in noninterest income marginally is associated with poorer risk-return tradeoffs on average. These findings suggest that the co-existence of noninterest income does not replace interest income from the intermediation activities that remain the core financial services function of banks.

Ivashina and Scharfstein (2008) of Havard Business School carried out a research study on lending by banks during the financial crisis of 2008 and found out that new loans to large borrowers decreased by $37 \%$ during the period when the financial crisis was at its peak (September -November 2008) relative to the three-month period before which lead to a decrease in profitability during the period. The credit levels of banks decreased by $68 \%$ in 2008 relative to the highest level of the credit boom (March-May 2007). The implication is that when lending to large and significant borrowers decrease the level of credit in banks decrease leading to a decrease in profitability. The situation becomes worse when the amounts of new loans extended to large borrowers ends up being non-performing as profits decreases even further as a result of loan loss provisioning. Good lending for real investment (such as capital expenditures) decreased to the same amount level as new lending for restructuring (share repurchases).

The authors (Ivashina and Scharfstein, 2008) argue that banks that were able to reach deposit financing reduced their lending with lesser amount than banks with less access to deposit financing. This is an indication that access to deposits enables banks to lend more meaning that there is a positive relationship between bank deposits and bank lending. Reduced 
lending may also have been curtailed because of large overhang of revolving credit facilities. Additionally, there was documentation of increased fluctuations of revolving credit that dealt with their ability to access funding. Although banks were helpful to the borrowers, the borrowers may limit the ability of banks to extend additional other loans if they do not pay their loans or if they default on their loans. Banks with many lines of revolving credit outstanding in relation to deposits decreased the amount of lending more than those with less revolving line exposure and by extension reduced profitability of the studied banks.

Honohan and King (2009) carried out a study on the effect of firm factors identified as size (total assets and capitalisation), profitability, ownership, years in banking and access to financial services. The findings were that whether banks were able to provide financial services to the firms was measured as a proportion of branches of banks located outside the major urban towns. Years in banking business is dependent on the number of years from the time the business as a bank was first licensed, ownership was categorised as either local or foreign, profitability was measured as bank's profit after tax and after adjusting for extraordinary items while size was measured using the total assets of the firm. Whether banks were able to provide financial services to the firms was measured as a proportion of branches of banks located outside the major urban towns. Regression results indicated that size as the main determinant of access to financial services was the most significant.

Barako et. al. (2013) undertook a study of specific factors of a firm and the way commercial banks in Kenyan provide financial services. Branch networks took the place of access to financial services while firm factors, namely, years in business, profitability, ownership and size were the independent variables. The findings were that firms' specific factors used which were identified as total assets and capitalisation are strongly and positively associated with access to financial services. The authors contend that large banks that have been in business for a longer period of time, banks that are foreign owned well capitalized banks and profitable banks are able to provide a variety of financial services and embrace financial innovations. These banks also tend to have diverse branch and ATM networks and tend to report more profits.

Kwaning et. al. (2014) uses a study of cases to explore the motivators of restructuring banks and the effects of bank restructuring on financial performance of one of Ghana's largest bank, Agricultural Development Bank (ADB). The findings of the study of $\mathrm{ADB}$ as an institution on restructuring shows that the factors that motivated ADB's restructuring were changes in the business environment, weak governance, poor strategic control, and poor performance. The impacts on the ADB's corporate governance, 
organizational structure and strategic control, performance, and employee costs lead to improved governance, a modified organizational structure, increased employee costs and a decrease in ADB's profitability.

\section{Research Problem}

The dilemma of whether bank restructuring is important in improving bank financial performance is yet to be resolved by researchers. Intervention through financial innovations, increasing the capital base to address the aspect of size and legal and regulatory framework review are important to ensure successful bank restructuring to record increased financial performance (Kwaning et. al., 2014). The financial sector in many economies is the main intermediary between savers who are interested in safe-keeping of their deposits and earning of interest income and borrowers who obtain loans at market rates of interest to finance profitable activities (Suehiro, 2002). In Kenya, commercial banks are increasingly offering new services such as mobile banking, agency banking, bank-assurance, faceless banking and integrating microfinance in their banking system (CBK, 2014). Well-capitalized banks provide a safety net for depositors, owners and even borrowers making them more preferable than their under-capitalized counterparts. Commercial banks in Kenya have undertaken restructuring to be more competitive, to improve bank solvency, to increase the banking sector capacity for financial intermediation and to improve performance. Although some commercial banks restructure as part of survival strategy, the CBK may require all banks experiencing a crises to restructure to reduce costs with the objective of increasing financial performance (CBK, 2014). The mergers and acquisitions of commercial banks in Kenya in the mid 1980's and late 1990's gave rise to bigger and more complex banking institutions which was aimed at improving profitability of the merged banks (Ithiri, 2013). To improve efficiency commercial banks have embraced modernized banking halls, broad ATM network, state of art technology, widespread branch network and agency banking (Das \& Ghosh, 2006). This has the longterm effect of increasing profitability of the resulting more efficient banks.

Dubel and Berlin (2013) researched on capital structure and practice of bank restructuring and found out that timing of bank restructuring is important. Beck et. al. (2007) researched on access to and use of banking services across selected countries and finds that large banks are better in providing a wider range of services because of their wider branch network. Espana (2015) researched on public financial assistance in the restructuring of Spanish banking sector emphasizing that government should take an active role in bank restructuring. Ithiri (2013) studied corporate restructuring and its effects on Kenya Commercial Bank performance and found out that 
the main drivers for restructuring were competition, company strategy, budgetary cuts, public pressure and change in government policy. Osoro (2014) undertook a study on the effect of financial restructuring on the financial performance of commercial banks in Kenya and found out that there exists an insignificant positive relationship.

Past studies did not demonstrate the intermediating effect of financial services as proxied by deposits and customer loans on the relationship between bank restructuring and bank financial performance. Although the studies cited above provide input to conceptual and methodological aspects to be used in this study, none of them researched on the intervening effect on the relationship between bank restructuring and financial performance of commercial banks therefore emphasizing on the need for this study.

\section{Data and Methodology}

The study relied on positivism philosophy and adopted descriptive causal research design for it involved analyzing of the relationship between bank restructuring and financial performance to determine the cause-effect implications. The study population was the 44 commercial banks operating in Kenya out of which 39 banks qualified as units of analysis as having data for the study period. Data was collected from the audited financial statements of the study banks using a standardized data collection sheet. The longitudinal panel data obtained covered a period of thirteen years for the period 2002 to 2014. Using SPSS version 21, inferential analysis was performed on the variables using hierarchical regression models. The financial performance was the independent variable and was operationalized using return on assets. Bank restructuring was the dependent variable and was measured using four proxies; namely, financial restructuring, capital restructuring, operational restructuring and asset restructuring. The intervening variable which was the financial services was proxied using deposits and customer loans. Further a composite variable for financial services was estimated as an arithmetic average of deposits and customer loans.

The intermediating effect of financial services was tested by adopting a procedure of a three steps methodology as shown below.

Step 1: Intermediation between Bank Restructuring and Financial Performance (Financial Services is constant)

$\mathrm{ROA}_{\text {it }}=\alpha_{\mathrm{r} 33}+\beta_{\mathrm{rf} 3} \mathrm{FR}_{\text {rit }}+\beta_{\mathrm{rc} 3} \mathrm{CR}_{\text {rit }}+\beta_{\mathrm{ro} 3} \mathrm{OR}_{\text {rit }}+\beta_{\mathrm{ra} 3} \mathrm{AR}_{\text {rit }}+\varepsilon_{\mathrm{r} 33} \ldots \ldots \ldots \ldots \ldots \ldots \ldots . . . . .1$

Where;

$\mathrm{ROA}_{\mathrm{it}}$ is return on assets for bank $\mathrm{i}$ in period $\mathrm{t}$

$\mathrm{FR}_{\text {rit }}$ is financial restructuring by firm $\mathrm{i}$ in period $\mathrm{t}$

$\mathrm{CR}_{\text {rit }}$ is capital restructuring by firm $\mathrm{i}$ in period $\mathrm{t}$

$\mathrm{OR}_{\text {rit }}$ is operational restructuring by firm $\mathrm{i}$ in period $\mathrm{t}$ 
$\mathrm{AR}_{\text {rit }}$ is asset restructuring by firm $\mathrm{i}$ in period $\mathrm{t}$

$\alpha_{\mathrm{r} 11, \text { is the constant term }}$

$\beta_{\mathrm{rf1} 1}, \beta_{\mathrm{rc} 1}, \beta_{\mathrm{ro} 1}$, and $\beta_{\mathrm{ra} 1}$ are the regression coefficients,

$i$ is income for bank $\mathrm{i}$ and $t$ is the year when the bank earns the income while $\varepsilon_{r 11}$ is the error term.

Step two: Intermediation between Financial Services (Deposits and Customer Loans) and Bank Restructuring (Financial Performance is constant)

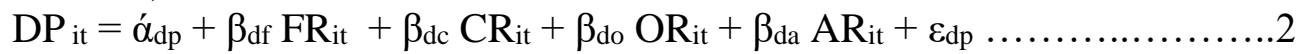

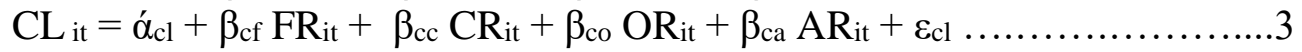

$\mathrm{FS}$ it $=\alpha_{\mathrm{dp}}+\beta_{\mathrm{df}} \mathrm{FR}_{\mathrm{it}}+\beta_{\mathrm{dc}} \mathrm{CR}_{\mathrm{it}}+\beta_{\mathrm{do}} \mathrm{OR}_{\mathrm{it}}+\beta_{\mathrm{da}} \mathrm{AR}_{\mathrm{it}}+\varepsilon_{\mathrm{dp}} \ldots \ldots \ldots \ldots \ldots \ldots \ldots . \ldots . \ldots \ldots$

Where;

FRrit is financial restructuring by firm $i$ in period $t$

$\mathrm{CR}_{\text {rit }}$ is capital restructuring by firm $\mathrm{i}$ in period $\mathrm{t}$

$\mathrm{OR}_{\text {rit }}$ is operational restructuring by firm $\mathrm{i}$ in period $\mathrm{t}$

$\mathrm{AR}_{\mathrm{rit}}$ is asset restructuring by firm $\mathrm{i}$ in period $\mathrm{t}$

DPrit is deposits of bank $i$ in period $t$

$\mathrm{CL}_{\text {rit }}$ is customer loans by bank $\mathrm{i}$ in period $\mathrm{t}$

$\mathrm{FS}_{\mathrm{rit}}$ is financial services provided by firm $\mathrm{i}$ in period $\mathrm{t}$

$\alpha_{\mathrm{dp}}-\alpha_{\mathrm{cl}}$ are the constants, $\beta_{\mathrm{df},} \beta_{\mathrm{dc}}, \beta_{\mathrm{do},} \beta_{\mathrm{da},} \beta_{\mathrm{cf},}, \beta_{\mathrm{cc}}, \beta_{\mathrm{co}}$ and $\beta_{\mathrm{ca}}$ are coefficients, $\varepsilon_{\mathrm{dp}}-\varepsilon_{\mathrm{cl}}$ are the error terms.

Step three: The intervening variables with significant coefficients $(\beta)$ were considered for further analysis. The intervening effect of deposits on the relationship between bank restructuring and financial performance was done based on equation stated below.

$\mathrm{ROA}_{\mathrm{it}}=\alpha_{\mathrm{r} 33}+\beta_{\mathrm{r} f 3} \mathrm{FR}_{\mathrm{rit}}+\beta_{\mathrm{rc} 3} \mathrm{CR}_{\mathrm{rit}}+\beta_{\mathrm{ro} 3} \mathrm{OR}_{\mathrm{rit}}+\beta_{\mathrm{ra} 3} \mathrm{AR}_{\mathrm{rit}}+\beta_{\mathrm{rd} 3} \mathrm{DP}_{\mathrm{rit}}+\varepsilon_{\mathrm{r} 33} \ldots .5$

The intervening effect of customer loans on the relationship between bank restructuring and financial performance is stated in equation 6 .

$\mathrm{ROA}_{\mathrm{it}}=\alpha_{\mathrm{r} 33}+\beta_{\mathrm{rr} 3} \mathrm{FR}_{\mathrm{rit}}+\beta_{\mathrm{rc} 3 \mathrm{CR}_{\mathrm{rit}}}+\beta_{\mathrm{rr} 3} \mathrm{OR}_{\mathrm{rit}}+\beta_{\mathrm{ra} 3} \mathrm{AR}_{\mathrm{rit}}+\beta_{\mathrm{r} 13} \mathrm{CL}_{\mathrm{rit}}+\varepsilon_{\mathrm{r} 33 . \ldots . . .6} 6$

For a variable to be intervening, its coefficient $\left(\beta_{\mathrm{rf} 3}, \beta_{\mathrm{rc} 3}, \beta_{\mathrm{ro} 3} \beta_{\mathrm{ra} 3}\right.$, $\beta_{\mathrm{rd} 3}$ and $\left.\beta_{\mathrm{rl} 13}\right)$ must be significant and the coefficient of the characteristic being mediated must be significant or significantly less when the mediator is included $\left(\beta_{\mathrm{rf} 3}<\beta_{\mathrm{rf} 1}, \beta_{\mathrm{rc} 3}<\beta_{\mathrm{rc} 1}, \beta_{\mathrm{r} 03}<\beta_{\mathrm{r} 01}, \beta_{\mathrm{ra} 3}<\beta_{\mathrm{ra} 1}, \beta_{\mathrm{rd} 3}<\beta_{\mathrm{rd} 1 \text {, and }} \beta_{\mathrm{rr} 3}<\beta_{\mathrm{rl} 11}\right)$

The study further sought the combine intervention of the deposits and customer loans as an arithmetic average of deposits and customer loans and the model equation is as stated below:

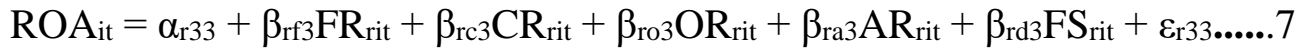
Where;

$\mathrm{ROA}, \mathrm{FR}, \mathrm{CR}, \mathrm{OR}, \mathrm{AR}, \alpha_{\mathrm{r} 33}, \beta_{\mathrm{rf} 3}-\beta_{\mathrm{r} 13}$, and it are as defined in equation 1, DP is deposit and CL customer loans, FS is financial services which is a composite value for deposits and customer loans while $\varepsilon_{\mathrm{r} 33}$ is the error term. 
Data on bank restructuring was analyzed using descriptive statistics of mean, standard deviation, skewness and kurtosis while hierarchical regression analysis was employed in establishing the relationship between the variables.

\section{Results and Discussion}

The data for the variables of the study consisted of 39 banks licensed to do banking business in Kenya and a summary of the descriptive statistics outcome as represented in Table 1 and 2 which generally depicted that indicators of both bank restructuring and financial performance were normally distributed with significant deviation. The linear regression results are as shown in Table 3.

Table 1: Summary of Descriptive Statistics for Financial Performance

\begin{tabular}{|c|c|c|c|c|c|c|c|c|c|c|c|}
\hline & $\mathrm{N}$ & Minimum & Maximum & Mean & $\begin{array}{c}\text { Std. } \\
\text { Deviation }\end{array}$ & \multicolumn{2}{|c|}{ Skewness } & \multicolumn{3}{|c|}{ Kurtosis } \\
\cline { 2 - 12 } & Statistic & Statistic & Statistic & Statistic & Statistic & Statistic & $\begin{array}{c}\text { Std. } \\
\text { Error }\end{array}$ & $\begin{array}{c}\text { Z - } \\
\text { Value }\end{array}$ & Statistic & $\begin{array}{c}\text { Std. } \\
\text { Error }\end{array}$ & $\begin{array}{c}\text { Z - } \\
\text { Value }\end{array}$ \\
\hline $\begin{array}{c}\text { Financial } \\
\text { Performance }\end{array}$ & 507 & .00 & 0.37 & 0.0275 & 0.02396 & 5.832 & 0.108 & 0.019 & 76.931 & .217 & 0.003 \\
\hline
\end{tabular}

Source: Research Findings

Table 2: Summary of Descriptive Statistics for Financial Services

\begin{tabular}{|c|c|c|c|c|c|c|c|c|c|c|c|}
\hline & \multirow{2}{*}{\begin{tabular}{|c|}
$\mathrm{N}$ \\
Statistic \\
\end{tabular}} & \multicolumn{2}{|c|}{ Minimum Maximum } & \multirow{2}{*}{\begin{tabular}{|l} 
Mean \\
Statistic
\end{tabular}} & $\begin{array}{c}\text { Std. } \\
\text { Deviation }\end{array}$ & \multicolumn{3}{|c|}{ Skewness } & \multicolumn{3}{|c|}{ Kurtosis } \\
\hline & & Statistic & Statistic & & Statistic & Statistic & \begin{tabular}{|l|} 
Std. \\
Error
\end{tabular} & \begin{tabular}{|c|}
$Z-$ \\
value
\end{tabular} & Statistic & \begin{tabular}{|l|} 
Std. \\
Error
\end{tabular} & $\begin{array}{c}Z \text { Z - } \\
\text { value }\end{array}$ \\
\hline Deposits & 507 & 0.00 & 0.98 & 0.6756 & 0.16964 & -1.963 & 0.108 & $\left|\begin{array}{c}- \\
0.055\end{array}\right|$ & 4.722 & 0.217 & 7 \\
\hline $\begin{array}{c}\text { Customer } \\
\text { loans }\end{array}$ & 507 & 0.00 & 0.99 & 0.5152 & 0.19580 & -0.392 & 0.108 & $\left|\begin{array}{c}- \\
0.276\end{array}\right|$ & 0.520 & 0.217 & 0.417 \\
\hline
\end{tabular}

Source: Research Findings

A composite variable for financial services was estimated and fitted in the regression equation to intervene for deposits and customer loans as indicated in Table 3. The dependent variable was financial performance while the independent variables were financial restructuring, capital restructuring, operational restructuring, asset restructuring, and financial services. The dependent variables explained 0.113 of the variability in profitability. This means that $11.3 \%$ of bank profitability is explained by financial restructuring, capital restructuring, operational restructuring, asset restructuring and financial services when the relationship between bank restructuring and financial services is intervened by financial services. 
Table 3: Regression Results of Mediating Effect of Financial Services on Bank Restructuring and Financial Performance

\begin{tabular}{|c|c|c|c|c|c|c|c|c|c|c|}
\hline \multicolumn{11}{|c|}{ Model Summary } \\
\hline \multicolumn{2}{|c|}{ Model } & \multicolumn{2}{|l|}{$\mathrm{R}$} & R Square & \multicolumn{4}{|c|}{ Adjusted R Square } & \multicolumn{2}{|c|}{$\begin{array}{l}\text { Std. Error of the } \\
\text { Estimate }\end{array}$} \\
\hline \multicolumn{2}{|c|}{1} & \multicolumn{2}{|c|}{$0.337^{\mathrm{a}}$} & 0.113 & \multicolumn{4}{|c|}{0.105} & \multicolumn{2}{|c|}{0.02268} \\
\hline \multicolumn{11}{|c|}{ ANOVA $^{a}$} \\
\hline \multicolumn{3}{|c|}{ Model } & \multicolumn{2}{|c|}{ Sum of Squares } & Df & \multicolumn{3}{|c|}{ Mean Square } & $\mathrm{F}$ & Sig. \\
\hline \multirow{3}{*}{1} & & egression & \multicolumn{2}{|c|}{0.033} & 5 & \multirow{2}{*}{\multicolumn{3}{|c|}{$\frac{0.007}{0.001}$}} & 12.813 & $0.000^{\mathrm{b}}$ \\
\hline & \multicolumn{2}{|r|}{ Residual } & \multicolumn{2}{|c|}{0.258} & 501 & & & & & \\
\hline & \multicolumn{2}{|r|}{ Total } & \multicolumn{2}{|c|}{0.291} & 506 & \multicolumn{3}{|c|}{0.001} & & \\
\hline \multicolumn{11}{|c|}{ Coefficients $^{\mathrm{a}}$} \\
\hline \multirow{2}{*}{\multicolumn{3}{|c|}{ Model }} & \multicolumn{2}{|c|}{$\begin{array}{l}\text { Unstandardized } \\
\text { Coefficients }\end{array}$} & \multirow{2}{*}{\multicolumn{2}{|c|}{$\begin{array}{c}\text { Standardized } \\
\text { Coefficients } \\
\text { Beta }\end{array}$}} & \multirow[t]{2}{*}{ t } & \multirow[t]{2}{*}{ Sig. } & \multicolumn{2}{|c|}{$\begin{array}{l}95.0 \% \text { Confidence } \\
\text { Interval for B }\end{array}$} \\
\hline & & & B & $\begin{array}{l}\text { Std. } \\
\text { Error }\end{array}$ & & & & & $\begin{array}{l}\text { Lower } \\
\text { Bound }\end{array}$ & $\begin{array}{l}\text { Upper } \\
\text { Bound }\end{array}$ \\
\hline \multirow{6}{*}{1} & & nstant) & 0.009 & 0.005 & & & 1.886 & 0.060 & 0.000 & 0.018 \\
\hline & $\begin{array}{r}\mathrm{Fi} \\
\text { rest }\end{array}$ & ncial & 0.011 & 0.006 & 0.075 & & 1.779 & 0.076 & -0.001 & 0.024 \\
\hline & $\begin{array}{r}\text { ( } \\
\text { rest }\end{array}$ & $\begin{array}{l}\text { apital } \\
\text { acturing }\end{array}$ & 0.103 & 0.015 & 0.316 & & 6.964 & 0.000 & 0.074 & 0.132 \\
\hline & $\begin{array}{l}\text { Op } \\
\text { rest }\end{array}$ & $\begin{array}{l}\text { tional } \\
\text { cturing }\end{array}$ & -0.047 & 0.026 & -0.082 & & -1.856 & .064 & -0.097 & 0.003 \\
\hline & rest & $\begin{array}{l}\text { set } \\
\text { cturing }\end{array}$ & -0.026 & 0.010 & -0.120 & & -2.570 & 0.010 & -0.046 & -0.006 \\
\hline & & $\begin{array}{l}\text { ncial } \\
\text { jices }\end{array}$ & 0.014 & 0.007 & 0.085 & & 1.915 & 0.056 & 0.000 & 0.028 \\
\hline
\end{tabular}

a. Dependent Variable: Financial Performance

Source: Research Findings model;

The mediation using financial services gives rise to the following $\mathrm{ROA}_{\mathrm{it}}=\alpha_{\mathrm{r} 33}+\beta_{\mathrm{rf} 3} \mathrm{FR}_{\mathrm{rit}}+\beta_{\mathrm{rc} 3} \mathrm{CR}_{\mathrm{rit}}+\beta_{\mathrm{ro} 3} \mathrm{OR}_{\mathrm{rit}}+\beta_{\mathrm{ra} 3} \mathrm{AR}_{\mathrm{rit}}+\beta_{\mathrm{rd} 3} \mathrm{FS}_{\mathrm{rit}}+\varepsilon_{\mathrm{r} 33}$ The output model therefore becomes; $\mathrm{ROA}=0.009+0.011 \mathrm{FR}+0.103 \mathrm{CR}-0.047 \mathrm{OR}-0.026 \mathrm{AR}+0.014 \mathrm{FS}+$ 0.005

The significant variables in the equation were capital restructuring and asset restructuring. Capital restructuring had a significant positive effect on profitability of the banks as denoted by the coefficient of $0.103(\mathrm{t}=$ 6.964) and a $\mathrm{p}$-value of 0.000 . Asset restructuring reported a significant negative effect on profitability with a coefficient of $-0.026(t=2.570)$ and a $\mathrm{p}$-value of 0.010 .

Financial restructuring, operational restructuring and financial services were found not to have significant influence on financial performance of commercial banks as they had coefficients of $0.011(\mathrm{t}$ $=1,779)$ and a $\mathrm{p}$ - value of $0.076,-0.047(\mathrm{t}=1.856)$ and a $\mathrm{p}-$ value of 0.064 
and $0.014(\mathrm{t}=1.915)$ and a $\mathrm{p}-$ value of 0.056 respectively. Financial services should however not be ignored by management of banks since they explain $1.4 \%$ of bank financial performance which is fairly significant as the $\mathrm{t}=$ 1.915 and the $\mathrm{p}-$ value is a borderline case of 0.056 .

Ivashina and Scharfstein (2008) find out that lending during a period of a financial crisis decreases profitability of banks. In addition, lending to large and significant borrowers decrease the level of credit banks leading to a decrease in profitability. Beck, Demirguc-Kunt and Peria (2007) found out that ensuring access to financial services has cost implications and can therefore lead to a decrease in profitability.

\section{Conclusion}

The objective of the study was to determine the intervening effect of financial services on the relationship between bank restructuring and financial performance of commercial banks in Kenya. The study relied on the Baron and Kenny (1986) to carry out the three steps methodology. The study concludes that bank restructuring affects financial performance of commercial banks in Kenya.

The disappointing revelation that bank restructuring only contribute to $10.2 \%$ of the profits of commercial banks is a pointer that whenever commercial banks are keen on significantly increasing financial performance, they should focus on other factors other than having to rely on bank restructuring. This contradicts the theory of financial intermediation that contends that for commercial banks to improve their financial performance, they need to improve their operations through improved processes, institutional capacity building and institutional innovation, as well as coming up with new products and services to increase their market share and therefore capture a wider customer base. This only explains outreach, enhances financial inclusion but appear not to have much effect on bank profitability.

Intervening the relationship between bank restructuring and financial performance reveals a positive effect on financial performance which is not too significant as the $\mathrm{t}$ value estimated was 1.915 and a $\mathrm{p}-$ value of 0.056 which is slightly above the threshold of 0.05 . The study results therefore conclude that the intervention of the relationship between bank restructuring and financial performance of commercial banks in Kenya may not be significant given the $\mathrm{p}-$ value of 0.056 .

\section{References:}

1. Adams, G. R., \& Schvaneveldt, J. D. (1991). Understanding research methods, 2e, Longman Publishing Group. 
2. Andries, A. M. \& Cuza, A. I. (2009). Theories regarding financial intermediation and financial intermediaries - A survey. The Annals of 'Stefan Cel Mare' University 2 (10), 254 - 261

3. Barako, D. G, Ross, T. \& Brown, M. (2013). Firm specific factors and access to financial services; University of New South Wales and Curtin University of Technology.

4. Baron, R. M. \& Kenny, D. A. (1986). The moderator-mediator variable distinction in social psychological research: Conceptual, strategic, and statistical considerations. Journal of Personality and Social Psychology, 51 (6), 151 - 173

5. Beck, T, Demirguc-Kunt, A. \& Peria M. (2007). Reaching out: Access to use of banking services across countries. Journal of Financial Economics. 85, 234 - 266

6. Birchil, J. \& Simmons, R. (2010). The co-operative reform process in Tanzania and Sri Lanka. Annals of Public and Co-operative Economics. 81(3), 467 - 500.

7. Central Bank of Kenya (2014). Central Bank of Kenya Bank Supervision Report

8. Chang, H., Ciana, M. A. \& Hsiao, H. C. (2014). First financial restructuring and operating efficiency: Evidence from Taiwan commercial banks. Drexel University and National Taipei College of Business.

9. Das, A. \& Ghosh, S. (2006). Financial deregulation and efficiency: An empirical analysis of Indian banks during the post reform period. Review of Financial Economics 15, 193 - 221.

10. De Young, R. \& Rice, T. (2003), Noninterest income and financial performance at U.S. commercial banks; Supervision and Regulation Department: Federal Reserve Bank of Chicago.

11. Dubel, H. J. \& Berlin, F. (2013). The Capital structure of banks and practice of bank restructuring; Eight case studies on current bank restructuring in Europe; Center for Financial Studies; University of Frankfurt.

12. Dupas, P. \& Robinson, J. (2009). Savings constraints and microenterprise development. Evidence from a field experiment in Kenya. The World Bank

13. Dziobek, C. \& Pazarbsioglu, C. (1998). Lessons from systemic bank restructuring; Economic Issues NO. 14, IMF.

14. Dziobek, C. (1998). Market-based policy instruments for systemic bank restructuring, IMF Working Paper, 98/113, IMF, Washington D.C.

15. Emilia, I., Gupta, D. D. \& Weisin, P. (2007). Toward developing a structured approach to the diagnosis and resolution of non- 
performing loans. The Case of China and India; School of Public Policy, George Mason University.

16. Espana, B. (2015). Public financial assistance in the restructuring of the Spanish banking sector. Journal of Financial Economics. 17, 211 $-256$

17. Fried, H. O., Lovell, C. A. K. \& Eeckaut, P. V. (1993). Evaluating the performance of U.S. credit unions. Journal of Banking and Finance. 17(5), $251-265$.

18. Hawkins, J. \& Turner, P. (1999). Bank restructuring in practice - An overview, in BIS, Bank Restructuring in Practice. BIS Policy Paper No. 6, Bank of International Settlements, Basel Switzerland.

19. Ho, S. J. K. \& Mckay, R. B. (2002). Balanced scorecard: Two perspectives. The CPA Journal. 12 (3) $20-25$

20. Hoenig, T. M. \& Morris, C. S. (2012). Restructuring the banking system to improve safety and soundness, Federal Deposit Insurance Corporation and Federal Reserve Bank of Kansas City.

21. Hoggarth, G., Reidhill J. \& Sinclair P. (2004). On the resolution of banking crises: Theory and evidence, Working Paper No. 229, Bank of England.

22. Honohan, P. \& King, M. (2009). Cause and effect of financial access: cross-country evidence from the Finscope surveys, paper prepared for the World Bank Conference Measurement promotion and impact of access to financial services, Washington DC, March.

23. Ithiri, M. D. (2013). Corporate restructuring and its effects on Kenya Commercial Bank performance. A Research Project in Masters of Business Administration, School of Business, Kenyatta University.

24. Ivashina, V. \& Scharfstain, D. (2008). Bank lending during the financial crisis of 2008. Harvard Business School.

25. John, K., Daunders, A. M., \& Senbet L. W. (1995). A theory of capital regulation and bank management compensation, Journal of Banking and Finance, 19, 23 - 57.

26. Kaplan, R. S. \& Norton, D. P. (1996). The balanced scorecard: Translating strategy into action. Havard Business School.

27. Kaplan, R. S. \& Norton, D. P. (2001). Transforming the balanced scorecard from performance measurement to strategic management. Harvard Business School.

28. Klein, P., Sharpiro, D. \& Young, J. (2005). Corporate governance, family ownership and firm value, the Canadian evidence. Corporate Governance: An International Review, 13 (6), 769 - 784.

29. Kwaning, C. O., Churchill, R. Q. \& Opuku, .A. K. (2014). The impact of organisational restructuring on the financial performance of public banks; A post restructuring assessment of Agricultural 
Development Bank, Ghana. Journal of Financial Accounting, 5, 106 $-112$

30. Lipe, M. \& Salterio, S. (2000). The balanced scorecard: Judgemental effects of common and unique performance measures. The Accounting Review. 287 - 298.

31. Mario, D. (2014). Bank restructuring and the economic recovery; The European Central Bank Eurosystem; Speech by the President of the ECB at the Presentation Ceremony of the Schumpeter Award, Oesterreichische National Bank, Vienna, March. Accessed from http://www.ecb.europa.eu.

32. Merton, R. C. (1995). Financial innovation and the management and regulations of financial institutions. Journal of Banking and Finance, $19,461-481$.

33. Moore, D. (2003). Survey of financial literacy in Washington State. Knowledge, behaviour, attitudes and experiences. Technical report, Social Economic Sciences Research Center. Washington State University.

34. Nor, F. M., Alias, N. \& Yaacob, M. H. (2009). Corporate restructuring, firm characteristics and performance, Jurnal Pengurusan, 27, 129 - 141

35. Roberts, M. R. (2007). Surprise and sense-making. What newcomers experience when entering unfamiliar organizational settings. Administrative Science Quarterly, 25, 226 - 251.

36. Rose, P. S. (1994). The rescue of troubled banks; consequences for corporate strategies to deal with financial and operating stress. Journal of Financial and Strategic Decisions. 7(2), 1 - 17

37. Suehiro, A. (2002). Restructuring and re-engineering of local commercial Banks in Thailand, Institute of Social Science, and University of Tokyo.

38. Waweru, M. A. S. (2008). Competitive strategy implementation and its effect on performance in large private sector firms in Kenya, Unpublished $\mathrm{PhD}$ Thesis, University of Nairobi.

39. Waggoner, D. Neely, A. \& Kennerley, M. (1999). The forces that shape organizational performance measurement systems. An interdisciplinary review. International Journal of Production Economics, 60(61), 533-60. 